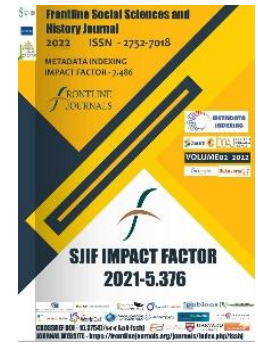

Journal Website: https://frontlinejournal s.org/journals/index.ph p/fsshj

Copyright: Original content from this work may be used under the terms of the creative commons attributes 4.0 licence.
Research Article

\section{ON THE QUESTION OF THE HISTORY OF UZBEK-GERMAN LITERARY AND CULTURAL RELATIONS (1960-1975)}

\author{
Submission Date: January 11, 2022, Accepted Date: January 21, 2022, \\ Published Date: January 31, 2022 \\ Crossref doi: https://doi.org/10.37547/social-fsshj-02-01-02 \\ Sadirjan Bakievich Yakubov \\ Associate Professor Of The Department Of German Philology, Faculty Of Foreign Philology Of The National \\ University Uzbekistan Named After Mirzo Ulugbek
}

\title{
Abstract
}

Productive value of a literary work depends on its functioning not only as an artistic text in a specific autonomous literary space, but also on how it is included in the context of social, cultural and literary factors of the world, reflects socio-cultural guidelines. It is precisely this inclusion in the world literary process that is ensured by literary contacts between different countries, the interaction of national literatures, and translation activities, because it is through translation that the popularization and functioning of any national literature in the global literary space is ensured.

Literary ties between Uzbekistan and Germany have their own history and interesting facets of modern interaction.

\section{KeYwords}

Uzbek-German literary, cultural relations, socio-cultural guidelines, Literary ties between Uzbekistan and Germany. 


\section{INTRODUCTION}

It is well known and indisputable that the productive value of a literary work depends on its functioning not only as an artistic text in a specific autonomous literary space, but also on how it is included in the context of social, cultural and literary factors of the world, reflects socio-cultural guidelines. It is precisely this inclusion in the world literary process that is ensured by literary contacts between different countries, the interaction of national literatures, and translation activities, because it is through translation that the popularization and functioning of any national literature in the global literary space is ensured.

The very development of national literatures, as is known, is impossible without interconnections with other literatures, mutual influence and mutual enrichment.

Literary ties between Uzbekistan and Germany have their own history and interesting facets of modern interaction. The most important stage is the time when the works of such prominent Uzbek writers as Navoi, Babur, A. Kadyri, A. Kahkhar, Aibek, G. Gulyam, Zulfiya, Sh. Rashidov and others began to be translated into many languages of the world, including into German (60s - 70s of the XX century).

German fiction is well known in Uzbekistan. The best works of outstanding representatives of German literature - Goethe, Schiller, Heine, Becher, Brecht, Wolf, Bredel, Zweig - were translated into many languages of the world, including by Uzbek translators.

\section{Methods}

The interaction and interconnection of literatures are directly related to the cultural and economic interaction of peoples.

In Germany, Uzbek culture and national art are treated with great interest. The enrichment and flourishing of any art is undoubtedly facilitated by the acquaintance and mutual exchange of the achievements of the national cultures of different peoples, which, of course, is due to expanding cultural ties.

Exhibitions, decades of cultural and artistic figures, seminars and symposiums, scientific conferences... Periodical press, scientific schools engaged in the study of foreign literatures and 
international literary relations, translation forums and seminars make a worthy contribution to the implementation of such relations and cooperation.

An important role in solving the problems of literary and cultural cooperation between the peoples of Germany and Uzbekistan is played by business contacts of the Writers' Unions of Germany and Uzbekistan, which organize international scientific symposiums, conferences, and translation forums.

The traditions of organizing such events were formed in the 60s and 70s of the last century.

A variety of art forms are successfully developing in Uzbekistan: theater, music, painting, cinema. Theatrical performances, performances, films are based on the work of the writer, so they are directly related to literature.

Many Uzbek films gained great popularity abroad, especially after the Second World War. Film screens of the world bypassed such films as "Tahir and Zuhra", "Nasreddin in Bukhara", "You are not an orphan", "Tenderness" and many others. The names of Kamil Yarmatov, Malik Kayumov, Ali Khamraev, Eler Ishmukhamedov, the famous actors Shukur Burkhanov, Khamza
Umarov, Dilorom Kambarova, Tamara Shakirova are not only known to German film lovers, but also loved.

The film of the talented director Ali Khamraev "The Seventh Bullet" is very popular abroad. This is evidenced by reviews and critical materials published in the German press. The newspaper "Berliner Zeitung" wrote: "The Uzbek director Ali Khamraev in his films talentedly showed us people who" fought for revolutionary ideas". This Uzbek film became a great event in the cultural life of the German people.

In February 1974, a week of films for children and youth took place in Berlin. In it, Uzbekistan was represented by the film directed by Kh. Fayziev "Semurg". This color film based on the Uzbek folk tale made a great impression on the German public.

A film story about the development of new lands in Uzbekistan "And Spring Came" was successfully shown in 1973 on the screens of Germany.

In 1978, the XXI International Film Festival in Leipzig was held. Here, Uzbekistan presented the film "Paranja" (studio of popular science and documentary films) by a prominent Uzbek 
screenwriter, People's Artist Malik Kayumov. The film, which tells about the life of Uzbek women before the revolution and in the postrevolutionary period, is designed for 5 minutes of screen time, however, it was awarded the highest prize of the Leipzig International Festival "Golden Dove", and director Malik Kayumov was awarded a diploma of the XXI International Film Festival for creating this film.

Thousands of German viewers applauded the songs performed by the Uzbek People's Artist Batyr Zakirov, who visited Germany at the invitation of the Directorate of Radio and Television in 1967.

In October 1968, the days of German culture and art were successfully held in Uzbekistan. Herman Genel, Ute Mai, Inga Kokhan, Urzula Heinrich, Gerhard Petzol and other talented German singers, dancers and musicians were very warmly received in Uzbekistan.

Kurt Mazur, chief conductor of the Dresden Philharmonic, wrote: "My dream was to visit Uzbekistan and have the opportunity to get acquainted and see the sights of Uzbekistan. Finally it happened." Other participants of the decade spoke enthusiastically about the country.
The expansion and deepening of cultural cooperation between the two peoples were facilitated by creative contacts between writers, cooperation between the Writers' Unions of Germany and Uzbekistan. An example of the multifaceted and fruitful activities of the Union of Writers of Uzbekistan was the conference of Asian and African countries, held in SeptemberOctober 1976.

Schiller's plays Robbers, Treachery and Love, Mary Stuart, the drama of the famous German playwright G. Hauptman Before Sunset were performed on the stages of Uzbek theaters.

Today, the study of interethnic literary contacts, mutual influence and mutual enrichment of literatures, the history of the formation of cultural interaction is one of the most urgent tasks of literary criticism, since the functioning of any national literature in the modern world is carried out only in active interaction with other literatures, which provides an opportunity to join the global "cultural field", organically coexist with time and space.

A lot of studies of Uzbek literary critics are devoted to the study of the interconnections of literatures and certain aspects of this problem, in 
particular, a number of works are devoted to some problems of Uzbek-German literary relations.

German literary critics show no less interest in international literary contacts.

However, it is impossible to consider that this problem has been sufficiently fully studied both in German and Uzbek literary criticism. The study of the problems of interaction between literatures, in particular, Uzbek-German contacts, continues to be relevant today.

German fiction in the 1920s emerged as one of the leading European literatures. And this is no coincidence: time itself and the greatest social transformations dictated by history gave rise to a number of major innovative artists who enriched German art.

Remarkable innovators appeared in prose, lyrics, drama, journalism: Johannes Robert Becher, Bertolt Brecht, Erich Weinert, Willy Bredel, Bodo Uze, F. Wolf and others.

In general, Uzbek-German literary cooperation dates back to ancient times and lasts for centuries: strong cultural ties were formed, common traditions were formed, there was an exchange of artistic values, that is, a process of mutual enrichment and interaction.

Academician K.I. Konrad rightly noted: "The problem of literary connections is one of the most important problems in the history of world literature, and it must be considered strictly historically, in all its historical concreteness."

In the 20s of the twentieth century, translations of the works of V. Hollander "The Adventures of Ibn Kamal" and "Unexpected Happiness" by Freyniel, carried out by Sanjar Siddik, translations of the works of F. Schiller "Robbers", "Deceit and Love", carried out by K. Yashen appeared in Uzbekistan and A. Mukhtar (1939).

These plays were staged on the stage of the Academic Theater. Khamza (Tashkent). The performances were warmly received by the public, which is evidence of the spiritual closeness of the peoples.

In the post-war period, after the formation of the GDR in 1949, Uzbek-German literary ties were intensively expanding. In 1955, F. Schiller's "William Tell" was published, translated by G. Gulyam. In the 60s, the Uzbek translator Malik Rahman translated E.Raspe's "The Adventures of Munchausen". 
The works of the prominent German writer, laureate of the prize "For Strengthening Peace Among Nations" Anna Zegers enjoyed great popularity in Uzbekistan.

Her novels "The Dead Remain Young" and "Across the Ocean" (The Story of One Love) were translated by Uzbek translators A. Abdullaev, Kh.

Ruzimatov and G. Ismailov, thanks to which the Uzbek reader got the opportunity to get acquainted with the best works of socialist realism.

In 1970, the 100th anniversary of the birth of the German writer Heinrich Mann was widely celebrated in Uzbekistan. The translation of his novel "The Loyal Subject" by M. Osim was timed to coincide with this date.

In the same year, a translation of the next work of the great German writer F. Schiller "Mary Stuart" was published. The works of the German classic Heinrich Heine were also translated into Uzbek. The pioneer of translation of his works into Uzbek is Aibek. His first translation of the work of G. Heine "Silesian weavers" appeared in 1938 in "Adabiyot reader" edited by H. Yakubov.

In the $40 \mathrm{~s}$ of the twentieth century, new translations of G. Heine appeared: "The Beautiful
Fisherwoman", "In May" carried out by A. Umari, "Pine" translated by G. Gulyam, "Lyric Poems" translated by Aibek and Mirtemir.

In the $60 \mathrm{~s}$, a new stage in the study of the heritage of the German poet begins, new talented translators declare themselves: H. Saloh, A. Sher, O. Holdor, R. Talipov, N. Mukhammadiev (Nasir), M. Kushmakov, S. Salomov, Zh. Suvonkulov, H. Nuri, N. Rakhimov, I. Jabbarov and others.

In the 1970 s, attempts were made to translate Goethe's works.

The writer M. Shaikhzade introduces the Uzbek reader to Goethe's work "South-Western Divan" for the first time.

In 1972-1974 the talented Uzbek poet and translator Erkin Vakhidov translated "Faust", which became a sensation in the literary life of Uzbekistan and contributed to the popularization of Goethe's heritage in Uzbekistan.

The translation into Uzbek of the sentimental novel "The Suffering of Young Werther", carried out by the Uzbek translator Yanglish Egamova in 1975 , opened a new page in the history of the Uzbek translation school. 
Talented translators sought to convey in the Uzbek interpretation not only the content, but also the spirit of the German original, proving that such pearls of German poetry as Faust, Goethe's The Sufferings of Young Werther and others can sound in full force in the Uzbek language.

These translations stimulated the development of international relations and the intensive, fruitful development of literary relations between the two peoples - Uzbek and German.

International cultural ties and translation activities, as rightly noted by many literary scholars and translators, contribute to the growth and enrichment of national literature, strengthen its authority in the global literary space, help to take its rightful place in the global literary process, serve to strengthen peace and progressive development of society.

Back in the 19th century, Germany showed an increased interest in Central Asia, its culture, literature, its past and present.

The translation of Baburname by Babur into German, carried out by the German translator and orientalist Kaiser in 1828, is a vivid example of this.
The German literary critic G. Dudak wrote: "Babur's works still serve as an important historical source today and have been translated into many European languages, including German."

In the second half of the 19th century, the Hungarian scholar G. Vambery translated several parts of the book "Kutadgu Bilik" into German, and the German orientalist Brokelmann translated fragments from "Devani Lugatit Turk".

Back in 1914, a translation of proverbs from the same "Devani lugatit Turk" was published, carried out by F. Hommel.

Uzbek literature, especially classics, is recognized in many countries of the world, including in the countries of the German language, in particular, in Germany. This is confirmed by numerous translations carried out in the twentieth century.

The translations of the works of the great Uzbek writer Alisher Navoi, carried out by the German translator Alfred Kurella in 1941, are a remarkable page in the history of interaction between Uzbek and German literature. 
Uzbek oral folk art, in particular fairy tales, was noted with great interest in Europe (the translation of Uzbek fairy tales was carried out in 1959 by M. Spadu).

In the 60s, German translated literature was replenished with translations of the works of Uzbek prose writers and novelists. The translation of the novel by the prominent Uzbek writer Abdulla Kahkhar "The Little Bird" (translator E. Brummer, publishing house "Kultur und Fortschritt" - 1961 and publishing house "Volk und Welt" - 1962) is an important event in the literary life of the German people. The preface to the book noted: "Abdulla Kahkhar is a great master of modern Uzbek prose", demonstrating the highest creative achievements of Uzbek literature.

In 1968, the publishing house "Kultur und Fortschritt" published a translation of Abdulla Kadiri's novel "Days Past" (translator Njota Thun).

The translation of another work by Abdullah Kadiri, The Scorpion from the Altar (translator Arno Specht, 1969), testifies to the growing popularity of the writer in Germany.
During this period, Khudaiberdy Tukhtabayev's story "The Magic Hat" (translator Helga Gutz), Utkur Khashimov's story "The Day of the Moth" (translator V. Plakmayer), Rakhmat Fayzi's novel "His Majesty is a Man" (translated by Kh. Galaikis) and many others were translated.

\section{Conclusion}

Interest in Uzbek literature revived in German literary criticism. The critical notes and translations of the German literary critic and writer Alfred Kurella are of a certain scientific value. Thanks to him, the German people learned about the work of many Uzbek writers, especially about Alisher Navoi. His book "Zwischendurch" ("Scattered Observations 1934-1940"), published in 1960 in Berlin, is a serious fundamental work on the creative heritage of A. Navoi. This is a great contribution to the popularization of the works of the Uzbek classic in Germany.

Cooperation and interaction in all branches of science, culture and literature is the most important phenomenon of social life, performing a significant socio-cultural function, contributing to the process of integration, strengthening friendship and mutual understanding, 
strengthening international ties, further development and mutual enrichment of cultures.

\section{REFERENCES}

1. Shavkat Mirziyoev. Uzbekistan and Germany: High-level dialogue based on mutual trust. Selected works. Volume IV. Tashkent, Uzbekistan Publishing House. 2019 y. Volume III, P. 311-314.

2. Shavkat Mirziyoev. Uzbekistan and Germany are reliable, important and long-term partners. Selected works. Volume IV. Tashkent, Uzbekistan Publishing House. 2019 y. Volume III, pages 315-319.

3. Newspaper "Berliner Zeitung", 1974, June 30, p. 10.

4. Magazine "Freie Welt", 1974, 727.

5. Узбекским друзьям. «Правда Востока», 1968, 10 октября.

6. Сб. Взаимосвязи и взаимодействия национальных литератур», М., 1961.

7. Interactions of literatures and artistic culture of developed socialism. Publishing house "Science", M., 1977.

8. G. Lomidze. Feeling of great community. Publishing house "Sov. pis., M., 1978.
9. Sharipov J. From the history of translation in Uzbekistan. T., «Fan», 1965, p.3-48.

10. Sharipov J. Literary translations and skilled translators. T., «Fan», 1972.

11. Salomov G.N. Language and translation. T., «Fan», 1966, p.5-38.

12. The art of translation. Gulom Publishing House of Literature and Art, T., 1978, pp.1040.

13. N. Otazhanov. Literary translation and scientific commentary (based on the translation of "Babur-name" into English). Abstract dis. ... cand. philol. Sciences. Tashkent, 1978.

14.S. Ochilov. Some Issues of Translation of German Poetry into Uzbek (Based on Translations of G. Heine's Poetry). Abstract dis. ... cand. philol. Sciences. - Tashkent, 1974.

15. Sh. Ruziev On the issue of Uzbek-German literary relations. Abstract cand. dis. Tashkent, 1974.

16. Ya. Egamova. On the issue of recreating the images of the characters of the original in literary translation. Abstract cand. dis. Tashkent, 1974. 
17.U. Satimov U. From the history of translations of works of German writers into Uzbek. Abstract cand. dis. - Tashkent, 1978.

18. Kurella A. Zwisehendurch 1934-1940. Aufbau Verlag. Berlin 1961.

19. Lexikon der Weltliteratur. Leipzig, 1965.

20. Christ R. Um die halbe Erde in Hundert Tagen (Reisegeschichten) Aufbau Verlag. Berlin. 1976.

21. Kisch E.E. Reportagen aus fünf Kontinenten. Verlag Filipp Reclam Jung Leipzig. 1976.

22. Konrad N.I. West and East. Ed. Eastern Literature. M., 1972, p.327.

23. Kachar A. Sekretär Saida. Verlag Volk und Welt. Berlin. 1962.

24. Multinationale Sowietliteratur. Kulturrevolution. Menschenbild (19171972) Aufbau Verlag. Berlin und Weimar. 1975.

25. Die Literaturen der Völker der Sowietunion. VEB Biblio-graphisches Institut. Leipzig. 1967.

26. Handbuch der Sowietliteratur (1917-1972). Leipzig. 1975.

27. Aragon L. «Literature Sovietique». Raris. 1955.
28. Konrad N.N. Middle Eastern Renaissance and Alisher Navoiy. - "Foreign Literature", No. 2, 1969, p. 217.

29. Alfred Curella. Theory and practice of translation. Report at the conference of translators, members, writers of the Writers' Union of the GDR, held on 12-13 / XII-54, in the article: "Translation Mastery". M., "Soviet writer", 1959.

30. Kodiri A. Die Liebenden von Taschkent. Berlin. 1968.

31. Kachar A. Sekretär Saida. Verlag Volk und Welt. Berlin. 1962. 